\title{
УТОЧНЕННЯ СУТНОСТІ ПОСЛУГИ У РИНКОВІЙ ЕКОНОМІЦІ
}

\section{Касатонова І.А., канд. екон. наук, доцент Харківський національний автомобільно-дорожній університет}

Постановка проблеми. У міру розвитку суспільства, росту виробничих сил відбувається швидке становлення сфери обслуговування. В даний час роль послуг, як одного $з$ найважливіших секторів економіки, напевно велика. Це можливо пов'язати з налагодженням виробничого циклу, накопиченням на ринку товарів як повсякденного, так і індивідуального попиту, 3 сильним ростом науково-технічного прогресу, котрий веде до новітніх технологій в житті суспільства. Все це не розглядається без існування інформаційних, фінансових, транспортних, страхових та інших видів послуг. Таким чином проблема підвищення рівня якості послуг для споживачів $є$ актуальною та потребує подальшого розгляду.

Аналіз останніх досліджень та публікацій. В даний час сфера послуг $є$ однією 3 найперспективніших, сильно розвинених галузей економіки. Вона охоплює велике коло діяльностей: від торгівлі і транспорту до фінансування, страхування і посередництва самого різного роду. Необхідно відмітити праці деяких дослідників: Т. Хілла, Ф. Котлера, М. Портера, К. Лавлока, Н. Понкратьєвої, В.Г. Шинкаренко, І.М. Климович. Науковці описують економічну природу послуг, корегують політико-економічну трактовку цієї категорії, пропонують перспективні напрямки всієї обслуговуючої галузі в поєднанні з ринковою трансформацією економіки.

У марксистській концепції відтворення суспільного продукту сутність послуги визначається як трудова цілеспрямована діяльність, наслідки якої задовольняють потреби населення. Тому, в цьому визначенні - розуміння послуги як виду діяльності. Продукція, що потрапляє на ринок, стає товаром, а послуга набуває властивості товару, якщо вона реалізується за економічно обгрунтованими цінами, коли перевищує витрати на надання послуги.

Широко відомо характеризування послуги як економічної категорії. М. Портер наголошує: «Термін послуги охоплює велике коло галузей, які здійснюють різноманітні функції для їх покупців, але не містять у собі продажів реального продукту» [1, с. 69].

Економічна корисність розглядає послуги предметом торгівлі. Таким чином, при обзорі функціональних особливостей послуги, Т. Хілл вважає, що послуга може бути розглянута «як зміна стану людини або предмета, яка належить будь-якому учаснику економічних відносин і досягається в результаті свідомих дій іншого учасника даних відносин. При цьому вплив відбувається на основі їх попередньої добровільної домовленості» [2, с. 121]. 
Ф. Котлер наводить досить розповсюджене визначення послуг, де він виділяє в послузі наявність матеріально-речовинної форми: «Послуга - будьякий захід або вигода, які одна сторона може запропонувати іншій і які в основному невловимі й не приводять до заволодіння чим-небудь. Виробництво послуг може бути, а може й не бути пов'язане з товаром у його матеріальному вигляді» [3, с. 638].

Отже, Ф. Котлер акцентує зір на значимих особливостях послуги: невідчутність, невіддільність від джерела, мінливість якості й несхоронність. Крім того, указується на те, що послуга: має корисність для когось, хто іiі не виконує; стає затребуваною в процесі обміну видами діяльності, впливає на основні умови виробництва й життєдіяльності людей.

У роботі «Економікс» К.Р. Макконела й С.Л. Брю зустрічається характеристика послуги як чогось не речовинного і в обмін на що споживач, підприємство або уряд готові представити щось цінне [4, с. 142].

Таку характеристику послуги приводить Н. Панкратьєва: «Послуги економічна діяльність, що на пряму задовольняє особисті потреби членів суспільства, домашніх господарств, потреби підприємств різних форм власності, об'єднань, організацій і суспільні потреби суспільства в цілому, не втілені в матеріально-речовинній форми» [5, с. 16].

Послуги можна розглядати як вид діяльності або робіт, у процесі виконання яких не створюється новий, який раніше не існував, матеріальноречовинний продукт, але змінюється якість уже існуючого, або створеного продукту [6, с. 282].

Сутність послуги можна розглядати 3 різних точок зору: як вид діяльності, як економічну категорію, як сферу, як грошовий потік. Визначення послуги як виду діяльності підтримує і В.Г. Шинкаренко і трактує послугу як «цінність, благо, вигоду, які отримує споживач у результаті дій, що надаються однією стороною іншій з метою задоволення запитів і полягають у зміні умов споживання виробів або стану самих споживачів» [7, с. 10].

В електронній енциклопедії послуги - це дії, результат яких споживається в процесі їхнього виконання. Вони подані як діяльність індивіда на користь іншої особи [8].

Невирішені складові загальної проблеми. У наш час дослідження ролі сфери послуг в економіці ведеться з позиції загальної теорії послуг. Щодо трактовки сутності послуг немає однозначного визначення. Зріст ролі сфери обслуговування, успіхи індустріально-сервісної моделі економічного росту потребують розгляду послуги як самостійної економічної категорії, уточнення iii сутності.

Формулювання цілей статті. Зріст ролі і впливу сфери послуг на економіку вказало на необхідність інтеграції підходів щодо сутності та складових послуг підприємства. Тому метою даної статті є уточнення сутності послуг у ринковій економіці.

Виклад основного матеріалу дослідження. Різноманітність підходів різних авторів до визначення терміна «послуга» змушує шукати необхідні 
структурні складові для складання певних груп й систематизації у відповідності зі своїми функціональними характеристиками. Теоретична особливість сутності послуг та їх класифікація наведені в таблиці 1.

Таблиия 1

Класифікаційні ознаки послуг

\begin{tabular}{|c|c|c|c|}
\hline № & Теоретичні підходи & $\begin{array}{c}\text { Ознаки } \\
\text { класифікації }\end{array}$ & Види послуг \\
\hline 1. & $\begin{array}{l}\text { Марксистська } \\
\text { концепція відтворення } \\
\text { суспільного продукту }\end{array}$ & Економічний зміст & $\begin{array}{l}\text { 1.1 Нематеріальні (чисті), } \\
1.2 \text { Матеріальні (послуги сфери } \\
\text { обігу) }\end{array}$ \\
\hline 2. & $\begin{array}{l}\text { Марксистська } \\
\text { концепція відтворення } \\
\text { суспільного продукту }\end{array}$ & Призначення & $\begin{array}{l}2.1 \text { Виробничого призначення, } \\
2.1 \text { Невиробничого призначення }\end{array}$ \\
\hline 3. & $\begin{array}{l}\text { Неокласична теорія } \\
\text { відтворення }\end{array}$ & $\begin{array}{l}\text { Джерела } \\
\text { фінансування }\end{array}$ & $\begin{array}{l}\text { 3.1 Ринкові, } \\
\text { 3.1 Неринкові }\end{array}$ \\
\hline 4. & $\begin{array}{l}\text { Концепція чистих } \\
\text { суспільних товарів і } \\
\text { послуг }\end{array}$ & Типи споживання & $\begin{array}{l}4.1 \text { Культурно-побутові і соціальні, } \\
4.2 \text { Суспільні (оборона, управління, } \\
\text { наука) }\end{array}$ \\
\hline 5. & $\begin{array}{l}\text { Концепція } \\
\text { споживання }\end{array}$ & $\begin{array}{l}\text { Характер } \\
\text { споживання }\end{array}$ & $\begin{array}{l}5.1 \text { Особисті (індивідуальні), } \\
5.2 \text { Суспільні (колективні) }\end{array}$ \\
\hline 6. & $\begin{array}{l}\text { Багатофакторні } \\
\text { концепції }\end{array}$ & Види & $\begin{array}{l}\text { 6.1 Транспорт і зв'язок, } \\
\text { 6.2 Житлово-комунальне } \\
\text { господарство, } \\
6.3 \text { Охорона здоров'я, фізична } \\
\text { культура і соціальна сфера, } \\
6.4 \text { Геологія, } \\
6.5 \text { Освіта, культура, мистецтво, } \\
\text { 6.6 Наука, } \\
6.7 \text { Фінансово-кредитне і страхове } \\
\text { забезпечення, } \\
6.8 \text { Торгівля і громадське постачання, } \\
6.9 \text { Туристичний і готельний бізнес } \\
6.10 \text { Управління суспільними } \\
\text { організаціями }\end{array}$ \\
\hline 7. & Концепція управління & $\begin{array}{l}\text { Суб’єкти, які } \\
\text { надають послуги }\end{array}$ & $\begin{array}{l}7.1 \text { Послуги державних закладів, } \\
7.2 \text { Послуги недержавних закладів, } \\
7.3 \text { Послуги фізичних осіб. }\end{array}$ \\
\hline
\end{tabular}

Таким чином, проаналізувавши різні трактування сутності послуги, пропонуємо таке уточнене іiї визначення: послуга - продукт праці, корисний ефект якого виступає не у формі товару, а у формі діяльності, спрямованої на людину. При цьому маємо на увазі, що послуга - це: продукт праці, який характеризується специфічними властивостями, такими, як непомітність, невіддільність від джерела, мінливість якості, несхоронність; діяльність, спрямована на людину, колектив, суспільство в цілому, процес виробництва $\mathrm{i}$ споживання специфічних корисностей, здійснення яких не пов'язане зі зміною речовинної форми й у той же час можливо змінити корисність речей і характер людської життєдіяльності. Новизна цього визначення у комплексному підході, який пропонує на підставі теоретичних основ та ознак класифікації тлумачити 
послугу як продукту праці у формі діяльності, яка у процесі виробництва i споживання людиною, колективом, суспільством змінює корисність речей i характер людської життєдіяльності. Цивільний кодекс України в статті 929, пункт 1 прямо вказує, що перевезення, транспортне експедирування $\epsilon$ послугами [9]. Транспортні послуги насамперед схожі між собою, оскільки вони на пряму пов'язані з процесом доставки. У той же час здійснюється доставка не повністю ідентичних об'єктів. Об'єктами транспортування можуть виступати вантажі, пасажири, багаж і вантажобагаж. В рамках вантажних перевезень можна окремо вивчати перевезення поштових відправлень, в рамках пасажирських - туристичні перевезення.

Транспортні послуги жорстко «прив’язані» до місця і часу, і тому вони невзаємозамінні, що обмежує внутрішньогалузеву конкуренцію на одному виді транспорту. Така конкуренція може бути між видами транспорту або при наявності альтернативних шляхів сполучення в рамках одного і того ж виду транспорту. В.Г. Шинкаренко, відстоюючи розширене трактування категорії «автотранспортна послуга», розуміє під нею «цінність, благо, вигоду, отримувану споживачем у процесі та після іiї надання, що полягає у зміні місця перебування пасажирів та вантажів. За своєю природою вона $є$ відчутною, оскільки у процесі транспортування пасажири та власники вантажів за допомогою органів чуття відчувають дію умов та якості транспортування» [10, c. 156]. Споживчі очікування клієнта транспортних послуг грунтуються на таких параметрах: мовних комунікаціях (чутках), тобто на інформації про послуги, яку споживачі послуг передають один одному; власних потребах (власних уявленнях клієнта щодо якості, його запитах); минулому досвіді, тобто на подібних послугах, що надавалися йому в минулому; зовнішніх комунікаціях, які поступають через засоби масової інформації: радіо, телебачення, пресу [11, с. 102]. Під транспортною послугою найчастіше розуміється переміщення вантажів i пасажирів. Транспортна послуга крім власне процесу перевезення, як прямого переміщення вантажу або пасажира транспортним засобом, містить у собі і інші операції та роботи, що не входять до складу транспортного перевізного процесу, але пов’язані з його підготовкою та здійсненням, такі як складські операції, вантажно-розвантажувальні роботи, експедирування та інші [12]. Зауважимо, що продукція транспорту (транспортна послуга) являє собою специфічний вид продукції по переміщенню вантажів і пасажирів, а ще по обслуговуванню супутніх та додаткових цього процесу операцій [13]. Автотранспортне підприємство являє собою головну складову частину загального ринку транспортних послуг, який в Україні формується з 1991 року. Під послугами транспорту розуміється діяльність, яка направлена на досягнення потреб населення, які виражені в формі попиту на перевезення вантажів або пасажирів, а також інші послуги, які пов'язані 3 процесом перевезень. Класифікацію послуг транспортного ринку можна здійснити за наданими ознаками: за ознакою взаємозв'язку з основною діяльністю підприємств транспорту послуги розподіляються на перевізні і не перевізні; за видом споживача, якому надається послуга - на зовнішні і внутрішні; залежно від 
виду та характеру послуг, що надаються, їх можливо підрозділити на транспортні, експедиційні, посередницькі; за характером діяльності, пов'язаної з наданням певної послуги - на технологічні, комерційні, інформаційні. Транспортні послуги $\epsilon$ часткою торгівлі товарами, так як в першу чергу здійснюють процес збуту та реалізації від виробника до споживача. Тому ми спостерігаємо збільшення занятості у цій сфері, ріст технічної оснащеності праці, впровадження новітніх технологій організації перевезень в нашій країні.

Висновки. Підвищення значимості сфери послуг, успіхи індустріальносервісної моделі економічного росту надали можливості розглядати послугу як самостійну економічну категорію, уточнити іiі сутність. Надано уточнене визначення поняття послуги, а саме як продукту праці у формі діяльності, яка у процесі виробництва і споживання людиною, колективом, суспільством змінює корисність речей i характер людської життєдіяльності. Новизна цього тлумачення у комплексному підході, який базується на підставі теоретичних основ та ознак класифікації послуг.

\section{Перелік посилань}

1. $\quad$ Портер М. Международная конкуренция. Москва, 1993. 267 с.

2. Маркова В.Д. Маркетинг услуг. Москва: Финансы, 1996. 326 с.

3. Котлер Ф. Основы маркетинга. Москва: Ростигр, 1996. 704 с.

4. Макконел Кэмпбелл Р. Экономикс: принципы, проблемы и политика: 2-е изд. Т.2. Москва: Республика, 1992. 400 с.

5. Панкратьева Н. Система статистических показателей сферы услуг как сектора экономики. Вопросы статистики. 1998. № 4. С. 16-21.

6. Клімович I.М. Сутність послуг у ринковій економіці. Вчені записки Харківського інституту управління. 2009. № 26. С. 281-286.

7. Шинкаренко В.Г. Автотранспортная услуга. Економіка транспортного комплексу. 2011. Вип. 18. С. 7-21.

8. Послуга: сайт. URL: https://uk.wikipedia.org/wiki (дата звернення: 9.03.2019).

9. Цивільний кодекс України (Відомості Верховної Ради України (ВВР): сайт. URL: http://zakon2.rada.gov.ua/laws/show/ (дата звернення: 7.03.2019).

10. Лаврова Ю.В., Горовий Д.А., Касатонова І.А. Маркетингова діяльність підприємств транспортного ринку. Харків: ХНАДУ, 2014. 356 с. $304 \mathrm{c}$.

11. Галабурда В.Г. Единая транспортная система. Москва: Транспорт, 2001.

12. Бачурин А.А. Маркетинг на автомобильном транспорте. Москва: Академия, 2005. 208 с.

13. Шинкаренко В.Г., Ананко I.M. Сутність споживчої цінності автотранспортної послуги. Економіка транспортного комплексу. 2013. Вип. 21. URL: http://etk-journal.khadi.kharkov.ua/fileadmin/journal/2013/21/ETK 21-2013.pdf (дата звернення: 13.02.2019)

\section{References}

1. Porter, M. (1993), International competition [Mezhdunarodnaya konkurentsiya], Moscow, $267 \mathrm{p}$. 
2. Markova, V.D. (1996), Service marketing [Marketing uslug], Moscow, Finance, $326 \mathrm{p}$.

3. Kotler, F. (1996), Marketing basics [Osnovy marketinga], Moscow: Rostigr, $704 \mathrm{p}$.

4. McConelle Campbell, R. (1992), Economics: principles, problems and policies [Ekonomiks: printsipy, problemy i politika], Moscow: Republic, 400 p.

5. Pankratieva, N. (1998), «The system of statistical indicators of the service sector as a sector of the economy» [«Sistema statisticheskih pokazatelej sfery uslug kak sektora jekonomiki»], Statistics Questions, No. 4, P. 16-21.

6. Klimovich, I.M. (2009), «The essence of services in a market economy», [«Sutnist posluh u rynkovii ekonomitsi»], Scientific notes of the Kharkov Institute of Management, No. 26, P. 281-286.

7. Shinkarenko, V. (2011), «Motor transport service» [«Avtotransportnaja usluga»], Economic transport complex, No. 18, P. 7-21.

8. Service [Posluga], available at: https://uk.wikipedia.org/wiki (last accessed 9.03.2019).

9. The Civil Code of Ukraine [Tsyvilnyi kodeks Ukrainy], available at: http://zakon2.rada.gov.ua/laws/show/ (last accessed 7.03.2019).

10. Lavrova, Yu.V., Gorovy, D.A., Kasatonova, I.A. (2014), Marketing activity of enterprises of the transport market [Marketynhova diialnist pidpryiemstv transportnoho rynku], Kharkiv: Publishing House KhNADU, 356 p.

11. Halaburda, V.G. (2001), Unified transport system [Edinaja transportnaja sistema], Moscow: Transport, $304 \mathrm{p}$.

12. Bachurin, A.A. (2005), Marketing by motor transport [Marketing na avtomobil'nom transporte], Moscow: Academy, $208 \mathrm{p}$.

13. Shynkarenko, V.G., Ananko, I.M. (2013), The essence of the consumer value of motor transport services [Sutnist spozhyvchoi tsinnosti avtotransportnoi posluhy], No. 21, available at: http://etkjournal.khadi.kharkov.ua/fileadmin/journal/2013/21/ETK 21-2013.pdf (last accessed 13.02.2019).

\section{РЕФЕРАТИ РЕФЕРАТЫ ABSTRAСТS}

\section{УДК 658:656.13.033; JEL Classification: M120}

Касатонова І.А. УТОЧНЕННЯ СУТНОСТІ ПОСЛУГИ У РИНКОВІЙ ЕКОНОМЦІ

Mema: метою даної роботи є узагальнення підходів щодо сутності та ознак послуг підприємства, а саме транспортної послуги. Сучасні умови господарювання, що характеризуються стрімким розвитком економічних систем вимагають від підприємств впровадження у практичну діяльність ефективних способів організації транспортних перевезень. Об'єкт дослідження - процес транспортних перевезень, який розглянуто з позиції транспортної послуги. Предмет дослідження - методичний інструментарій впливу на транспортну послугу як економічну категорію на сучасному етапі ринкової економіки країни. Методика дослідження: дослідження проводилися шляхом 
аналізу наукових робіт по темі і меті даної статті, які були надані як зарубіжними науковцями, так і вітчизняними. В роботі використані методи теоретичного узагальнення, аналізу та синтезу інформації, формалізації. Результати дослідження: у статті розглянуті теоретичні засади економічної категорії «послуга», визначається роль послуг в умовах ринкових відносин, розглянуто структурні елементи послуги та їх класифікацію. Також визначено сутність поняття «автотранспортна послуга» на підставі узагальнення сучасних підходів провідних вчених. Наукова новизна: встановлено, що послуга - це продукт праці, корисний ефект якого виступає не у формі товару, а у формі діяльності, спрямованої на людину. Новизна цього визначення у комплексному підході, який базується на підставі теоретичних основ та ознак класифікації послуг. Практична значущість: здійснено класифікацію транспортних послуг на ринку транспортних перевезень за наступними ознаками: економічний зміст, призначення, джерела фінансування, типи споживання, характер споживання, види, суб’ єкти, які надають послуги.

Ключові слова: послуга; транспортна послуга; транспортні перевезення; сфера послуг; продукт праці; корисний ефект.

\section{УДК 658:656.13.033; JEL Classification: M12}

\section{Касатонова И.А. УСТАНОВЛЕНИЕ СУЩНОСТИ УСЛУГИ В РЫНОЧНОЙ ЭКОНОМИКЕ}

Цель: целью данной работы является обобщение подходов к сущности и признаков услуг предприятия, а именно транспортной услуги. Современные условия хозяйствования, характеризующихся стремительным развитием экономических систем требуют от предприятий внедрения в практическую деятельность эффективных способов организации транспортных перевозок. Объект исследования - процесс транспортных перевозок, который рассмотрено с позиции транспортной услуги. Предмет исследования - методический инструментарий влияния на транспортную услугу как экономическую категорию на современном этапе рыночной экономики страны. Методика исследования: исследования проводились путем анализа научных работ по теме и цели данной статьи, которые были предоставлены как зарубежными учеными, так и отечественными. В работе использованы методы теоретического обобщения, анализа и синтеза информации, формализации. Результаты исследования: в статье рассмотрены теоретические основы экономической категории «автотранспортная услуга», определяется роль услуг в условиях рыночных отношений, рассмотрены структурные элементы услуги и их классификацию. Также определено сущность понятия «услуга» на основании обобщения современных подходов ведущих ученых. Научная новизна: установлено, что услуга - это продукт труда, полезный эффект которого выступает не в форме товара, а в форме деятельности, направленной на человека. Новизна данного определения в комплексном подходе, который базируется на основании теоретических подходов и составляющих классификации услуг. Практическая значимость: осуществлено классификацию транспортных услуг на ринке транспортных перевозок по 
следующим признакам: экономическое содержание, назначение, источники финансирования, типы потребления, характер потребления, виды и субъекты, оказывающие услуги.

Ключевые слова: услуга; транспортная услуга; транспортные перевозки; сфера услуг; продукт труда; полезный эффект.

\section{UDC 658:656.13.033; JEL Classification: M120}

Kasatonova I.A., DETERMINATION OF ESSENCE OF THE SERVICE IN MARKET ECONOMIC

Purpose: the purpose of this work is to generalize the approaches to the essence and features of the services of the enterprise, namely motor transport services. Current economic conditions are characterized by the sheer development of economic systems require from companies implementations into practice the effective methods of transportation organization. The object of research is the processes of transportation. There are seen in position of motor transport service. The subject of research is methodical tools of influence of transport services have been explored as economic category in modern step of economic of country. Methodology of research: the study has been carried out through an analysis of scientific papers on the topic. The methods of theoretical generalization, analysis and synthesis of information, formalization are used in the article. Findings: in the article theoretical principles of economic category «service» axe examined, the role of services is determined in the conditions of market relations, the structural elements of service and their classification are given. The essence of the term «motor transport service» have been determined and based on generalization of modern approaches of the prominent scientists too. Originality: it is established that a service is a product of labor, the beneficial effect of which is not in the form of goods, but in the form of activity directed towards a person. The novelty of this definition in the integrated approach is based on the theoretical foundations and features of the classification of services. Practical value: classification is carried out according to the following features: economic content, purpose, sources of financing, types of consumption, nature of consumption, types, and entities providing services.

Key words: service; motor transport service; transportation; services sector; product of labor; beneficial effect.

\section{Відомості про авторів / Сведения об авторах / About the Authors}

Касатонова Інна Анатоліївна - кандидат економічних наук, доцент, Харківський національний автомобільно-дорожній університет, доцент кафедри управління та адміністрування, м. Харків, Україна; е-mail: kasatonova82@gmail.com. Моб.068-607-87-38.

Касатонова Инна Анатольевна - кандидат экономических наук, доцент, Харьковский национальный автомобильно-дорожный университет, доцент кафедры управления и администрирования, г. Харьков, Украина.

Kasatonova Inna - Candidate of Sciences (Economics), Associate Professor, Kharkov National Automobile and Highway University, Associate Professor at the Department of Management and Administration, Kharkov, Ukraine. 